\title{
PENERAPAN METODE BERMAIN PERAN UNTUK MENINGKATKAN KEMAMPUAN MEMBEDAKAN DAN MENGELOMPOKKAN SAMPAH BERDASARKAN ORGANIK DAN ANORGANIK PADA SISWA TK AL AZHAR SYIFA BUDI
}

\author{
Oleh: \\ Fatimah Dahlan \\ TK AL Al Azhar Syifa Budi Surakarta
}

\begin{abstract}
Abstrak
Peneliti telah melakukan penelitian untuk meningkatkan kemampuan membedakan dan mengelompokan sampah berdasarkan organik dan anorganik di TK Al-Azhar Syifa Budi Solo Kecamatan Laweyan, Surakarta, dari semua tindakan yang peneliti ambil dalam penelitian ini dapat diambil simpulan sebagai berikut: 1. Metode pembelajaran bermain peran di dalam rangka untuk meningkatkan kemampuan anak dalam membedakan jenis sampah Organik dan Anorganik anak adalah suatu pilihan yang tepat dan cermat, 2. Metode Pembelajaran bermain peran dapat meningkatkan kemampuan untuk membedakan dan mengelompokan sampah sesuai jenisnya ( organik dan anorganik), hal ini dapat dilihat dari paparan data perkembangan dari siklus I ke siklus berikutnya yang terdapat perkembangan secara signifikan. Dapat dengan jelas dilihat dari kemampuan anak yang semula hanya mencapai $57 \%$. Dengan penggunaan metode tepat dan cermat akhirnya kemampuan anak untuk dapat membedakan dan mengelompokan sampah sesuai jenisnya berubah menjadi $92 \%$.
\end{abstract}

Kata Kunci: Metode Bermain Peran, Meningkatkan Kemampuan, Membedakan dan Mengelompokan Sampah

\section{Pendahuluan}

Pendidikan Anak Usia Dini merupakan pendidikan yang menyenangkan dengan prinsip "belajar sambil bermain, bermain seyara belajar". Berangkat dari sinilah pembelajaran yang ada di TK harus dicermati, sehinga apa yang diharapkan, yakni agar anak-anak lebih mandiri dalam segala hal sesuai dengan kapasitas anak bisa tercapai. Metode pengajaran yang tepat dan cermat akan mengarahkan anak-anak pada hasil yang optimal. Penerapan keterampilan proses dalam pembelajaran di PAUD perlu dikembangkan, salah satunya dengan pendekatan pembelajaran dengan metode bermain peran. Melalui metode ini, siswa didorong untuk secara aktif terlibat langsung dengan diberikan arahan dari guru. Pada akhirnya, siswa diharapkan memiliki kemampuan menguasai konsep. Keterlibatan siswa secara aktif dalam metode pembelajaran ini dapat membantu mereka memecahkan permasalahan yang nyata dan merespon secara aktif. Kesulitan siswa dalam membedakan sampah organik dan anorganik dapat disebabkan oleh beberapa faktor diantaranya yaitu karena pembiasaan pola asuh dari rumah dan juga minimnya stimulus mengenai berbagai jenis sampah dan cara memperlakukannya. Kesulitan ini pun dapat dipengaruhi oleh faktor kemampuan kognitif dari 
setiap siswa itu sendiri. Dari hasil observasi yang teramati dalam kegiatan sehari-hari sebenarnya membedakan sampah organik dan anorganik tidaklah sulit, akan tetapi siswa kesulitan dalam penerapannya dalam kehidupan sehari-hari. Siswa merasa sulit untuk membuang sampah yang sesuai dengan tempatnya, dalam kenyataan tidak semua tempat telah tersedia tempat sampah yng terpisah berdasarkan jenisnya. Berdasarkan latar belakang di atas dan untuk lebih mempertajam kemampuan anak PAUD terutama kelompok A dalam membedakan sampah organik dan anorganik maka guru perlu memperbaiki metode pembelajaran yang selama ini dilakukan, dengan mengajak anak untuk terlibat secara langsung dalam kegiatan membedakan dan mengelompokan sampah berdasarkan jenisnya. Pembelajaran yang dilakukan yaitu dengan menggunakan metode bermain peran.

Menurut Lilis Suryani (2008 : 109), bermain peran adalah memerankan karakter/tingkah laku dalam pengulangan kejadian yang diulang kembali, kejadian masa depan, kejadian yang masa kini yang penting, atau situasi imajinatif. Anak-anak pemeran mencoba untuk menjadi orang lain dengan memahami peran untuk menghayati tokoh yang diperankan sesuai dengna karakter dan motivasi yang dibentuk pada tokoh yang telah ditentukan. Bermain peran berarti menjalankan fungsi sebagai orang yang dimainkannya, misalnya berperan sebagai dokter, ibu guru, nenek tua renta.

Bermain peran sering digunakan untuk mengajarkan masalah tanggung jawab warga negara, kehidupan sosial, atau konseling kelompok.metode ini memberikan kesempatan kepada anak untuk mempelajari tingkah laku manusia.

Berdasarkan latar belakang masalah di atas, maka peneliti dapat merumuskan masalah penelitian sebagai berikut: Bagaimanakah metode bermain peran di TK Al-Azhar Syifa Budi Solo?, Sejauh manakah kemampuan anak kelompok A dalam membedakan sampah organik dan anorganik di TK Al-Azhar Syifa Budi Solo?, Sejauh manakah metode bermain peran dalam meningkatkan kemampuan anak untuk membedakan sampah organik dan anorganik pada anak kelompok TKA di TK Al-Azhar Syifa Budi Solo? Berdasarkan rumusan masalah di atas maka tujuan penelitian ini adalah. 1.Untuk mengetahui metode bermain peran disentra peran di TK AL-Azhar Syifa Budi Solo, 2. Untuk mengetahui sejauh manakah kemampuan kognitif anak kelompok A dalam membedakan sampah organik dan anorganik di TK AlAzhar Syifa Budi Solo, 3. Untuk mengetahui sejauh manakah metode bermain peran dalam meningkatkan keterampilan kognitif anak untuk membedakan sampah organik dan anorganik pada anak kelompok TKA di TK Al-Azhar Syifa Budi Solo. Dengan demikian dapat ditarik kesimpulan mengenai hipotesis sebagai berikut : Menggunakan metode bermain peran dapat 
meningkatkan kemampuan kognitif anak dalam membedakan sampah organik dan anorganik anak TK kelompok A di TK Al-Azhar Syifa Budi Solo.

Manfaat bagi siswa adalah 1) Dapat meningkatkan kemampuan membedakan dan mengelompokan sampah sesuai dengan jenisnya 2) Mengikuti proses pembelajaran dengan perasaan senang, dan aktivitas belajar yang tinggi. Manfaat bagi guru adalah 1) Dengan pelaksanaan penelitian Tindakan Kelas ini, guru memiliki pengetahuan, ketrampilan, dan pengalaman tentang Penelitian Tindakan Kelas, khususnya dengan menerapkan model pembelajaran bermain peran, 4) Guru dapat berinovasi dalam pembelajaran di dalam kelas. Guru dapat mencari solusi atau pemecahanmasalah pembelajaran yang ada di kelas. Manfaat bagi sekolah adalah: Sekolah akan sangat diuntungkan dengan adanya perbaikan pembelajaran oleh guru melalui Penelitian Tindakan Kelas (PTK), Dengan adanya pembelajaran yang inovatif akan meningkatkan aktivitas belajar anak yang akan bermuara pada peningkatan motivasi belajar siswa. Motivasi belajar siswa tersebut akan mempengaruhi prestasi sekolah secara umum. Untuk kepentingan tersebut Pembahasan dalam penelitian ini difokuskan, pada penggunaan metode bermain peran kaitannya dengan kemampuan kognitif anak kelompok A. Penelitian ini dilakukan di TK Al-Azhar Syifa Budi Solo.

\section{Kajian Teori}

\section{A. Konsepsi Metode Pengajaran}

"Metode adalah merupakan cara utama yang bersifat umum dan luas yang digunakan untuk mencapai suatu tujuan." (Surahman, 1978: 121). Sedangkan pengajaran adalah, "1 proses, perbuatan, cara mengajar atau mengajarkan; 2 perihal mengajar; segala sesuatu mengenai mngajar.” (Tim. 1996: 13). Dengan demikian metode pengajaran berarti suatu cara utama yang bersifat umum dan luas dalam melakukan proses, perbuatan, cara mengajar, atau mengajarkan untuk mencapai suatu tujuan.

\section{B. Konsepsi Metode Pengajaran "BERMAIN PERAN" Pengertian Bermain Peran}

Metode bermain peran adalah berperan atau memainkan peranan dalam dramatisasi masalah sosial atau psikologis. Bermainperan adalah salah satu bentuk permainan pendidikan yang di gunakan unutk menjelaskan perasaan, sikap, tingkah laku dan nilai, dengan tujuan untuk menghayati perasaan, sudut pandangan dan cara berfikir orang lain (Depdikbud, 1964:171). Pengertian Bermain Peran atau Role Playing menurut Kamus Bahasa Indonesia (Badudu-Zain, 84) adalah mengambil bagian 
dalam melakukan suatu kegiatan yang menyenangkan baik dengan menggunakan alat atau tanpa alat. Pengertian Bermain Peran atau Role Playing menurut Prof. Dr. H. Endang Komara, M.Si.,bermain peran adalah kegiatan yang mengeksplorasi hubungan antar manusia dengan cara memperagakan dan mendiskusikan sehingga orang dapat mengeksplor perasaan, sikap, nilai,dan berbagai strategi pemecahan masalah. Pengertian Bermain Peran atau Role Playing Menurut Corsini, (dalam Tatiek 92001: 99) mengemukakan bahwa bermain peran suatu alat belajar yang mengembangkan ketrampilan-ketrampilan dan pengertian-pengertian mengenai hubungan antar manusia dengan jalan memerankan situasi-situasi yang paralel dengan yang terjadi dalam kehidupan yang sebenarnya. Selanjutnya, Corsini, dalam Tatiek (2001: 99) menyatakan bahwa bermain peran dapat digunakan sebagai: (a) alat untuk mendiagnosis dan mengerti seseorang dengan cara mengamati perilakunya waktu memerankan dengan spontan situasi dan kejadian yang terjadi dalam kehidupan sebenarnya.(b) media pengajaran,melalui proses "modeling" anggota dapat lebih efektif melalui ketrampilanketrampilan antar pribadi dengan mengamati berbagai cara dalam memecahkan masalah.(c) metode latihan untuk melatih ketrampilan-ketrampilan tertentu melalui keterlibatan secara aktif dalam proses bermain peran. Melalui Metode bermain peran siswa diajak untuk belajar memecahkan masalah pribadi, dengan bantuan kelompok sosial yang anggotanya temantemannya sendiri. Dengan kata lain Metode ini berupaya membantu individu melalui proses kelompok sosial.

Supriyati berpendapat dalam buku Metode Pengembangan Prilaku dan Kemmapuan Dasar Anak Usia Dini (2008 : 109), bermain peran adalah permainan yang memerankan tokoh-tokoh atau benda-benda sekitar anak sehingga dapat mengembangkan daya khayal (imajinasi) dan penghayatan terhadap bahan kegiatan yang dilaksanakan. Bermain peran berarti menjalankan fungsi sebagai orang yang dimainkannya, misalnya berperan sebagai dokter, ibu guru, nenek tua renta ataupun peran-peran yang lainnya sesuai dengan yang diinginkan. Bermain peran sering digunakan untuk mengajarkan masalah tanggung jawab warga negara, kehidupan sosial, atau konseling kelompok.metode ini memberikan kesempatan kepada anak untuk mempelajari tingkah laku manusia. Pengertian bermain peran menurut buku didaktik metodik di Taman Kanak-Kanak (Depdikbud 1998) adalah memerankan tokoh-tpkoh atau benda-benda di sekitar anak dengan tujuan untuk mengembangkan daya khayal (imajinasi) dan penghayatan terhadap bahan pengembangan yang dilaksanakan. 


\section{Konsepsi Sampah Organik dan Anorganik}

Sampah adalah buangan yang dihasilkan dari suatu proses produksi baik industri maupun domestik (rumah tangga). Sementara didalam UU No 18 Tahun 2008 tentang Pengelolaan Sampah, disebutkan sampah adalah sisa kegiatan sehari hari manusia atau proses alam yang berbentuk padat atau semi padat berupa zat organik atau anorganik bersifat dapat terurai atau tidak dapat terurai yang dianggap sudah tidak berguna lagi dan dibuang kelingkungan. Sampah berasal dari beberapa tempat, yakni :

1. Sampah dari pemukiman penduduk pada suatu pemukiman biasanya sampah dihasilkan oleh suatu keluarga yang tinggal disuatu bangunan atau asrama. Jenis sampah yang dihasilkan biasanya cendrung organik, seperti sisa makanan atau sampah yang bersifat basah, kering, abu plastik dan lainnya.

2. Sampah dari tempat-tempat umum dan perdagangan tempat tempat umum adalah tempat yang dimungkinkan banyaknya orang berkumpul dan melakukan kegiatan. Tempattempat tersebut mempunyai potensi yang cukup besar dalam memproduksi sampah termasuk tempat perdagangan seperti pertokoan dan pasar. Jenis sampah yang dihasilkan umumnya berupa sisa-sisa makanan,sayuran busuk, sampah kering, abu, plastik, kertas, dan kaleng-kaleng serta sampah lainnya.

Jenis-Jenis Sampah

Jenis-jenis sampah jenis sampah yang ada di sekitar kita cukup beraneka ragam, ada yang berupa sampah rumah tangga, sampah industri, sampah pasar, sampah rumah sakit, sampah pertanian, sampah perkebunan, sampah peternakan, sampahninstitusi/ kantor/ sekolah, dan sebagainya. Berdasarkan asalnya, sampah padat dapat digolongkan menjadi 2 (dua) yaitu sebagai berikut :

1. Sampah organik, adalah sampah yang dihasilkan dari bahan-bahan hayati yang dapat didegradasi oleh mikroba atau bersifat biodegradable. Sampah ini dengan mudah dapat diuraikan melalui proses alami. Sampah rumah tangga sebagian besar merupakan bahan organik. Termasuk sampah organik, misalnya sampah dari dapur, sisa-sisa makanan, pembungkus (selain kertas, karet dan plastik), tepung, sayuran, kulit buah, daun dan ranting. Selain itu, pasar tradisional juga banyak menyumbangkan sampah organik seperti sampah sayuran, buah-buahan dan lain-lain.

2. Sampah Anorganik adalah sampah yang dihasilkan dari bahan-bahan non hayati, baik berupa produk sintetik maupun hasil proses teknologi pengolahan bahan tambang. Sampah anorganik dibedakan menjadi : sampah logam dan produk-produk olahannya, 
sampah plastik, sampah kertas, sampah kaca dan keramik, sampah detergen. Sebagian besar anorganik tidak dapat diurai oleh alam/ mikroorganisme secara keseluruhan (unbiodegradable). Sementara, sebagian lainnya hanya dapat diuraikan dalam waktu yang lama. Sampah jenis ini pada tingkat rumah tangga misalnya botol plastik, botol gelas, tas plastik, dan kaleng, (Gelbert dkk, 1996).

\section{Metode Penelitian}

Pendekatan yang digunakan dalam penelitian ini sesuai dengan sifat penelitian adalah pendekatan kualitatif karena dalam penelitian ini lebih mengutamakan deskreftif analitik untuk memecahkan konsep-konsep di dalamnya; bukan menggunakan numeric statistik. Penelitian ini adalah penelitian tindakan kelas. Rangkaian tindakan akan melalui tahapantahapan, yakni tahapan perencanaan, tindakan, pengamatan, analisis dan refleksi. Dari hasil analisis dan refleksi setiap akhir kegiatan dilakukan perbaikan pada siklus berikutnya. Metode pembelajaran yang digunakan dalam penelitian ini adalah metode bermain peran makro untuk menarik perhatian siswa pada saat pembelajaran.

Rancangan Penelitian

\begin{tabular}{|c|c|c|}
\hline Siklus I & $\begin{array}{l}\text { Perencanaan } \\
\text { Identifikasi masalah } \\
\text { dan penetapan } \\
\text { alternatif masalah }\end{array}$ & $\begin{array}{l}\text { 1. Menentukan tema } \\
\text { 2. Membuat satuan kegiatan harian } \\
\text { 3. Mempersiapkan alat peraga/sumber belajar } \\
\text { 4. Menyiapkan tempat } 2 \text { tempat sampah yang berbeda } \\
\text { ( hijau = Organik, Merah = Anorganik) } \\
\text { 5. Menyiapkan instrumen observas } 1\end{array}$ \\
\hline & Tindakan & $\begin{array}{l}\text { 6. Melaksanakan pengajaran dengan metode bermain } \\
\text { peran dengan menginventarisir tokoh-tokoh yang } \\
\text { diperlukan, bermacam-macam jenis sampah organik } \\
\text { dan anorganik dengan benda nyata sesuai dengan } \\
\text { kebutuhan. } \\
\text { 7. Mengelompokkan anak dari anak } 26 \text { menjadi } \\
\text { kelompok } \\
\text { 8. Setiap satu kelompok ( } 13 \text { anak ) dibagi lagi menjadi } \\
3 \text { kelompok peran yang dimainkan } \\
\text { 9. Kelompok } 1 \text { berperan sebagai ibu-ibu rumah tangga } \\
\text { 10. Kelompok } 2 \text { berperan sebagai anak sekolah } \\
\text { 11. Kelompok } 3 \text { berperan sebagai petugas kebersihan } \\
\text { 12. Guru memberikan arahan untuk setiap tokoh yang } \\
\text { diperankan } \\
\text { 13. Guru memberikan penjelasan mengenai cara } \\
\text { mengelompokan jenis sampah kedalam tempat } \\
\text { sampah yang berbeda dengan simbolnya masing- } \\
\text { masing } \\
\text { 14. Semua kelompok bermain sesuai dengan perannya } \\
\text { masing-masing }\end{array}$ \\
\hline
\end{tabular}




\begin{tabular}{|c|c|c|}
\hline & & $\begin{array}{l}\text { 15. Anak masih terihat bingung dalam memerankan } \\
\text { tokohnya } \\
\text { 16. Keterlibatan anak secara langsung dalam } \\
\text { mengelompokan sampah berdasarkan jenisnya masih } \\
\text { belum optimal }\end{array}$ \\
\hline & Pengamatan & $\begin{array}{l}\text { 17. Melakukan observasi dengan menggunakan format } \\
\text { data observasi tindakan kelas dengan kreteria } \\
\text { penilaian } \\
\text { 18. BB = Belum mampu } \\
\text { 19. M = Mampu }\end{array}$ \\
\hline & Refeksi & $\begin{array}{l}\text { 20. Objek penelitian sebanyak } 13 \text { anak yang dibagi } \\
\text { dengan } 3 \text { kelompok peran dalam pelaksanaan } \\
\text { kegiatan pembelajaran konsentrasi anak belum focus } \\
\text { masing-masing anak masih terlihat canggug dalam } \\
\text { memainkan perannya } \\
\text { 21. Pelaksanaan kegiatan kelompok praktik membedakan } \\
\text { sampah organik dan anorganik belum berhasil secara } \\
\text { maksimal. }\end{array}$ \\
\hline $\begin{array}{l}\text { Siklus } \\
\text { II }\end{array}$ & $\begin{array}{l}\text { Perencanaan } \\
\text { Identifikasi masalah } \\
\text { dan penetapan } \\
\text { alternatif masalah }\end{array}$ & $\begin{array}{l}\text { 1. Menentukan tema } \\
\text { 2. Membuat satuan kegiatan harian } \\
\text { 3. Mempersiapkan alat peraga/sumber belajar } \\
\text { 4. Menyiapkan } 2 \text { tempat sampah yang berbeda ( hijau } \\
\text { = Organik, Merah = Anorganik) } \\
\text { 5. Menyiapkan instrumen observasi } 2\end{array}$ \\
\hline & Tindakan & $\begin{array}{l}\text { 6. Melaksanakan pengajaran dengan metode bermain } \\
\text { peran dengan menginventarisir tokoh-tokoh yang } \\
\text { diperlukan, bermacam-macam jenis sampah organik } \\
\text { dan anorganik dengan benda nyata sesuai dengan } \\
\text { kebutuhan. } \\
\text { 7. Mengelompokkan anak dari anak } 26 \text { anak menjadi } 2 \\
\text { kelompok besar dan } 1 \text { kelompok besar dibagi lagi } \\
\text { menjadi } 3 \text { kelompok tokoh } \\
\text { 8. Kelompok } 1 \text { berperan sebagai ibu-ibu rumah tangga } \\
\text { 9. Kelompok } 2 \text { berperan sebagai anak sekolah } \\
\text { 10. Kelompok } 3 \text { berperan sebagai petugas kebersihan } \\
\text { 11. } 1 \text { orang berperan menjadi guru } \\
\text { 12. Guru memberikan arahan peran dari tokoh yang akan } \\
\text { dimainkan } \\
\text { 13. Guru memberikan penjelasan mengenai cara } \\
\text { mengelompokan jenis sampah kedalam tempat } \\
\text { sampah yang berbeda dengan simbolnya masing- } \\
\text { masing } \\
\text { 14. Semua kelompok bermain sesuai dengan perannya } \\
\text { masing-masing } \\
\text { 15. Anak terlibat secara langsung untuk mengelompokan } \\
\text { sampah organik dan anorganik dengan benda nyata } \\
\text { yang telah disediakan dengan }\end{array}$ \\
\hline & Pengamatan & $\begin{array}{l}\text { 16. Melakukan observasi dengan menggunakan format } \\
\text { data observasi tindakan kelas dengan kreteria }\end{array}$ \\
\hline
\end{tabular}




\begin{tabular}{|c|c|}
\hline & $\begin{array}{l}\text { penilaian } \\
\text { 17. } \mathrm{BB}=\text { Belum mampu } \\
\text { 18. } \mathrm{M}=\mathrm{Mampu} \\
\text { 19. Mengumpulkan data observasi }\end{array}$ \\
\hline Refeksi & $\begin{array}{l}\text { 20. Objek penelitian sebanyak } 13 \text { anak dari } 26 \text { anak } \\
\text { yang sudah dibagi } 2 \text { kelompok anak dalam } \\
\text { pelaksanaan kegiatan pembelajaran konsentrasi } \\
\text { lebih fokus masing-masing dengan kehadiran } 1 \\
\text { peran tambahan peran guru sebagai pengarah } \\
\text { tema, anak sudah terlihat luwes dalam } \\
\text { memainkan perannya } \\
\text { 21. Pelaksanaan kegiatan kelompok praktik } \\
\text { membedakan sampah organik dan anorganik dapat } \\
\text { berhasil secara maksimal. } \\
\text { 22. Pengumpulan data observasi } \\
\text { 23. Rekapitulasi nilai }\end{array}$ \\
\hline
\end{tabular}

Adapun sumber data dalam penelitian ini adalah guru dan siswa TK Al-Azhar Syifa Budi Solo kelompok A Kec. Laweyan Surakarta. Dalam mendapatkan data yang diperlukan dalam penelitian ini, maka peneliti menggunakan beberapa tehnik yaitu sebagai berikut : 1 . Observasi dan 2. Dokumentasi. Untuk mengetahui keberhasilan dalam proses pembelajaran diperlukan evaluasi secara menyeluruh.

\section{A. Indikator Kinerja}

Kriteria yang digunakan untuk mengukur keberhasilan dan kegagalan pembelajaran dapat dicermati melalui keaktifan siswa dalam proses pembelajaran dan evaluasi kegiatan dan keberhasilan belajar anak adalah sejauh mana anak paham dan mengerti perbedaan dari sampah organik dan anorganik.

B. Kriteria Keberhasilan

Kriteria untuk mengukur tingkat pencapaian keberhasilan pembelajaran dalam membedakan sampah organik dan anorganik dinyatakan telah mencapai tujuan pembelajaran jika total jumlah anak yang mampu membedakan sampah organik dan anorganik mencapai angka diatas $85 \%$.

\section{Lokasi Penelitian}

Lokasi penelitian yang diambil oleh peneliti adalah TK Al-Azhar Syifa Budi Solo Kec. Laweyan Kota Surakarta, Provinsi Jawa Tengah. Penelitian ini dilakukan selama 3 bulan terhitung dari bulan September sampai dengan bulan November 2016. 


\section{Hasil Penelitian dan Pembahasan}

\section{A. Deskripsi Kondisi Awal}

Kemampuan membedakan dan mengelompokan sampah sesuai jenisnya siswa kelompok TKA masih rendah. Siswa yang sudah mampu dalam membedakan dan mengelompokan sampah dengan benar adalah 6 siswa dari 26 siswa, dan 18 siswa yang belum mampu. Aktivitas belajar anak juga masih perlu diperkaya lagi supaya pembelajaran menjadi lebih variatif dan lebih memotivasi siswa dalam memperoleh pengetahuannya.

B. Hasil Penelitian

\section{Siklus $I$}

1) Perencanaan

Pada tahap perencanaan guru melakukan penyusunan RPP beserta lembar observasi menunjuk teman sejawat yang akan ditunjuk sebagai observer, dan menyiapkan kelas yang akan digunakan untuk penelitian.

2) Pelaksanaan

Siklus I terdiri dari 2 pertemuan. Pelaksanaan tindakan dalam penelitian siklus I ini berjalan sesuai apa yang telah direncanakan. Pada pertemuan I dan II difokuskan pada pelaksanaan bermain peran dengan tema "Kerja Bakti". Observer mengamati segala tindakan yang dilakukan oleh guru dan siswa. Pada pertemuan ketiga kegiatan dilakukan untuk mengulas materi yang telah diterangkan dan didiskusikan pada pertemuan sebelumnya. Kegiatan yang difokuskan untuk pertemuan ketiga adalah pengukuran kemampuan berhitung siswa melalui tes formatif.

\section{3) Observasi}

Observasi dilakukan oleh teman sejawat yang bernama Ibu Hesti Puspitasari, S.Si. Pengamatan dilakukan pada pertemuan pertama dan kedua. Pengamat mengambil posisi di belakang kelas. Adapun hasil pengamatannya adalah sebagai berikut:

Kemampuan membedakan siswa pada siklus I telah dianalisis dengan tingkat ketuntasan anak yang mampu membedakan dan mengelompokan yaitu sebanyak 15 siswa, masih ada 11 siswa yang belum mampu membedakan dan memngelompokan sampah sesuai jenisnya.

\section{4) Refleksi}

Berdasarkan hasil evaluasi Siklus I pertemuan ketiga dapat dilihat adanya peningkatan. Perbandingan kemampuan membedakan dan mengelompokan siswa dapat dilihat pada tabel 1 berikut: 


\begin{tabular}{|l|l|l|l|l|l|}
\hline No & $\begin{array}{l}\text { Kemampuan } \\
\text { membedakan } \\
\text { dan } \\
\text { mengelompokan }\end{array}$ & Kondisi Awal & Siklus I \\
\cline { 2 - 6 } & Frekuensi & Persentase & Frekuensi & Persentase \\
\hline 1 & Mampu & 6 & $23 \%$ & 15 & $57 \%$ \\
\hline 2 & Belum Mampu & 20 & $76 \%$ & 11 & $42 \%$ \\
\hline & Jumlah & 26 & $100 \%$ & 26 & $100 \%$ \\
\hline
\end{tabular}

Hasil pada siklus I belum mencapai indikator kinerja, maka penelitian perlu dilanjutkan pada siklus II karena belum mencapai ketuntasan belajar sesuai dengan indikator kinerja. Adapun refleksi dari pelaksanaan siklus I adalah sebagai berikut: Masih ada beberapa siswa yang belum bersungguh-sungguh dalam mengikuti kegiatan bermain peran ; siswa masih terlihat canggung dan bingung dalam memerankan tokohnya. Guru belum memberikan penjelasan dan bimbingan yang lebih jelas pada semua kelompok dalam kegiatan bermain peran.

\section{Siklus II}

\section{1) Perencanaan}

Pada tahap perencanaan guru melakukan penyusunan RPP beserta lembar observasi menunjuk teman sejawat yang akan ditunjuk sebagai observer, dan menyiapkan kelas yang akan digunakan untuk penelitian.

\section{2) Pelaksanaan}

Siklus II terdiri dari 2 pertemuan. Pelaksanaan tindakan dalam penelitian siklus II ini berjalan sesuai apa yang telah direncanakan. Pada pertemuan I dan II difokuskan pada pelaksanaan bermain peran dengan tema "Kerja Bakti"dengan menambah 1 tokoh karakter yang berbeda dari siklus I agar siswa mendapat 1 bimbingan dari 1 tokoh yang berperan sebagai guru.

\section{3) Observasi}

Observasi dilakukan oleh teman sejawat yang bernama Ibu Hesti Puspitasari, S.Si. Pengamatan dilakukan pada pertemuan pertama dan kedua. Pengamat mengambil posisi di belakang kelas. Adapun hasil pengamatannya adalah sebagai berikut: Kemampuan siswa dalam membedakan dan mengelompokan sampah sesuai jenisnya pada siklus II telah dianalisis dengan tingkat ketuntasan sebagai berikut. Siswa yang mampu membedakan dan mengelompokan adalah 24 siswa atau 92\% dan belum mampu 2 siswa atau $8 \%$.

4) Refleksi 
Kondisi kelas lebih kondusif dibandingkan dengan siklus I. siswa tampak antusias mengikuti proses pembelajaran. Peneliti juga lebih lancar dalam menyampaikan materi. Berdasarkan hasil evaluasi observasi pada siklus I dan Siklus II dapat dilihat adanya peningkatan. Perbandingan kemampuan membedakan dan mengelompokan sampah organic dan anorganik siswa dapat dilihat pada tabel 2 berikut:

\begin{tabular}{|c|c|c|c|c|c|}
\hline \multirow[t]{2}{*}{ No } & \multirow{2}{*}{$\begin{array}{l}\text { Kemampuan } \\
\text { membedakan } \\
\text { dan } \\
\text { mengelompokan }\end{array}$} & \multicolumn{2}{|l|}{ Siklus I } & \multicolumn{2}{|l|}{ Siklus II } \\
\hline & & Frekuensi & Persentase & Frekuensi & Presentase \\
\hline 1 & Mampu (BB) & 15 & $57 \%$ & 24 & $92 \%$ \\
\hline 2 & $\begin{array}{l}\text { Belum Mampu } \\
\text { (M) }\end{array}$ & 11 & $42 \%$ & 2 & $8 \%$ \\
\hline & Jumlah & 26 & $100 \%$ & 26 & $100 \%$ \\
\hline
\end{tabular}

Dari tabel di atas dapat kita lihat bahwa terjadi peningkatan kemampuan siswa dari siklus I ke siklus II. Terjadi persentase ketuntasan belajar siswa, rata-rata kemampuan siswa dalam membedakan dan mengelompokan sampah sesuai jenisnya yang diperoleh siswa juga meningkat. Ketuntasan belajar dalam membedakan dan mengelompokan sampah sesuai jenisnya siswa telah mencapai $92 \%$.

\section{Pembahasan}

Berdasarkan hasil penelitian dan tindakan yang telah dilaksanakan dapat dinyatakan cukup berhasil. Penerapan model pembelajaran bermain peran di sentra peran dianggap dapat meningkatkan kemampuan membedakan dan mengelompokan sampah organuk dan anorganik siswa kelompok A di TK Al-Azhar Syifa Budi Solo. Karena dari masing-masing pertemuan ada peningkatan kemampuan siswa dari hasil observasi yang telah dilaksanakan. Hal tersebut akan dianalisis dalam pembahasan berukut.

\section{Gambaran Metode Bermain Peran Untuk Meningkatkan Kemampuan Anak dalam Membedakan Sampah Organik dan Anorganik.}

Berdasarkan hasil penelitian dan tindakan yang telah dilaksanakan dapat dinyatakan bahwa pembelajaran melalui pengunaan model Pembelajaran bermain peran di sentra peran dapat meningkatkan kemampuan dalam membedakan dan mengelompokan sampah organik dan anorganik siswa kelompok A semester I tahun pelajaran 2016/2017. Hal tersebut dapat kita lihat dalam tabel 3 berikut: 
Tabel Perbandingan Kemampuan Siswa Per siklus

\begin{tabular}{|c|c|c|c|}
\hline \multirow[t]{2}{*}{ No } & \multirow[t]{2}{*}{ Nama } & \multicolumn{2}{|c|}{$\begin{array}{c}\text { Membedakan \& Mengelompokan Sampah organik } \\
\text { dan anorganik }\end{array}$} \\
\hline & & SIKLUS I & SIKLUS II \\
\hline 1 & Abdurrahman Kaarim A & $\mathrm{M}$ & $\mathrm{M}$ \\
\hline 2 & David Raissa Permana Erland & $\mathrm{BB}$ & $\mathrm{M}$ \\
\hline 3 & Dimas Raditya Syahreza & $\mathrm{M}$ & $\mathrm{M}$ \\
\hline 4 & Disya Zallfa Nadhiff H & $\mathrm{M}$ & $\mathrm{M}$ \\
\hline 5 & Eijaz Ramadhan F & $\mathrm{M}$ & $\mathrm{M}$ \\
\hline 6 & Felicia Rifda Khairunnisa & $\mathrm{M}$ & $\mathrm{M}$ \\
\hline 7 & Gendhis Budiarto & $\mathrm{BB}$ & $\mathrm{M}$ \\
\hline 8 & Gevurah Noor Kusuma & $\mathrm{BB}$ & $\mathrm{BB}$ \\
\hline 9 & Ghaisan Ahmad Paramaditya & $\mathrm{M}$ & $\mathrm{M}$ \\
\hline 10 & Hanefi Mulia Hartono & $\mathrm{BB}$ & $\mathrm{M}$ \\
\hline 11 & Ibrahim Faris Haidar & $\mathrm{BB}$ & $\mathrm{M}$ \\
\hline 12 & Jean Aleandro Febriosa & $\mathrm{M}$ & $\mathrm{M}$ \\
\hline 13 & Keanu Zacky Alvaro & $\mathrm{M}$ & $\mathrm{M}$ \\
\hline 14 & Kinan Yasha Almahyra & $\mathrm{BB}$ & $\mathrm{M}$ \\
\hline 15 & Kirana Cahya Dewi H & $\mathrm{M}$ & $\mathrm{M}$ \\
\hline 16 & Maurizka Fellisiana Putri & $\mathrm{M}$ & $\mathrm{M}$ \\
\hline 17 & Muhammad Arjuna D & $\mathrm{BB}$ & $\mathrm{M}$ \\
\hline 18 & Muhammad Keisha Fawwaz & $\mathrm{BB}$ & $\mathrm{M}$ \\
\hline 19 & Muhammad Naafi & $\mathrm{BB}$ & $\mathrm{M}$ \\
\hline 20 & Nabila Putri Febrian & $\mathrm{M}$ & $\mathrm{M}$ \\
\hline 21 & Naura Zahwa Syahida K & $\mathrm{BB}$ & $\mathrm{BB}$ \\
\hline 22 & Nayla Zalfa Kalilatama & $\mathrm{BB}$ & $\mathrm{M}$ \\
\hline 23 & Rayyan Arafa Pasadzani & $\mathrm{M}$ & $\mathrm{M}$ \\
\hline 24 & Satria Abrisam Caesar Faeyza & $\mathrm{M}$ & $\mathrm{M}$ \\
\hline 25 & Talita Charis Nadifah & $\mathrm{M}$ & $\mathrm{M}$ \\
\hline 26 & Kevin Vanda M & $\mathrm{M}$ & $\mathrm{M}$ \\
\hline
\end{tabular}

Kreteria Nilai:

$\mathrm{BB}:$ Belum mampu $\quad \mathrm{M}$ : Mampu
Surakarta, 3 November 2016

Guru Kelompok A

Perkembangan keberhasilan metode bermain peran di TK Al-Azhar Syifa Budi Solo yang diteliti dapat dilihat pada tabel berikut:

\begin{tabular}{|l|l|c|c|}
\hline \multirow{2}{*}{ No. } & Pertemuan & \multicolumn{2}{|c|}{ Hasil yang Dicapai } \\
\cline { 3 - 4 } & $\begin{array}{c}\text { Siswa } \\
\text { membedakan \& } \\
\text { mengelompkan } \\
\text { jenis sampah }\end{array}$ & $\begin{array}{c}\text { Presentsi } \\
\text { Keberhasilan }\end{array}$ \\
\hline 1 & Siklus I & 15 & $57 \%$ \\
\hline 2 & Siklus II & 24 & $92 \%$ \\
\hline
\end{tabular}




\section{Simpulan}

Peneliti telah melakukan penelitian untuk meningkatkan kemampuan membedakan dan mengelompokan sampah berdasarkan organik dan anorganik di TK Al-Azhar Syifa Budi Solo Kecamatan Laweyan, Surakarta, dari semua tindakan yang peneliti ambil dalam penelitian ini dapat diambil simpulan sebagai berikut: 1. Metode pembelajaran bermain peran di dalam rangka untuk meningkatkan kemampuan anak dalam membedakan jenis sampah Organik dan Anorganik anak adalah suatu pilihan yang tepat dan cermat, 2. Metode Pembelajaran bermain peran dapat meningkatkan kemampuan untuk membedakan dan mengelompokan sampah sesuai jenisnya ( organik dan anorganik), hal ini dapat dilihat dari paparan data perkembangan dari siklus I ke siklus berikutnya yang terdapat perkembangan secara signifikan. Dapat dengan jelas dilihat dari kemampuan anak yang semula hanya mencapai $57 \%$. Dengan penggunaan metode tepat dan cermat akhirnya kemampuan anak untuk dapat membedakan dan mengelompokan sampah sesuai jenisnya berubah $92 \%$.

\section{Daftar Pustaka}

Asmani, Jamal Ma’ruf. 2011. Penelitian Tindakan Kelas. Jogjakarta : Laksana

Bowo, A. N. A. (2012). Strategi Index Card Match untuk Peningkatan Pemahaman Siswa SMK Mata Pelajaran PKn. Academy of Education Journal, 3(1).

Djamarah. 2002. Strategi Belajar Mengajar. Jakarta : Rineka Cipta

Iskandar. 2011. Penelitian Tindakan Kelas. Jakarta : GP Press

Kayvan, Umy.2009. Permainan Kreatif untuk Mencerdaskan Anak. Jakarta : Media Kita.

Moleong, Lekxy J. 2000. Metodologi Penelitian Kualitatif. Bantung: PT Remaja.

Saleh, Chasman. 1988. Pedoman Guru Bidang Pengembangan kemampuan Berbahasa di Taman Kanak-Kanak. Jakarta: Departeman Pendidikan dan Kebudayaan.

Nurani, Yuliani. 2012. Konsep Dasar Pendidikan Anak Usia Dini. Jakarta : PT Indeks

Tim PKP PG PAUD.2008. Panduan Pemantapan Kemampuan Profesion. Jakarta : Universitas Terbuka.

Tim. 1990 Kamus Besar Bahasa Indonesia. Jakarta: Balai Pustaka

Tim. 1996. Pedoman Guru Bidang Pengembangan Berbahasa di Taman Kanak-Kanak. Jakarta: Departemen Pendidikan. Dan Kebudayaan. 